\title{
An adventitious distal abscissa in the forewing of honey bees (Hymenoptera: Apidae: Apis)*
}

\author{
Ken TAN ${ }^{1,2}$, Stefan FUCHS ${ }^{3}$, Michael S. ENGEL ${ }^{4}$ \\ ${ }^{1}$ Xishuangbanna Tropical Botanical Garden, Chinese Academy of Science, Kunming, Yunnan Province, 650223, \\ People's Republic of China \\ ${ }^{2}$ Eastern Bee Research Institute of Yunnan, Agricultural University, Heilongtan, Kunming, Yunnan Province, \\ People's Republic of China \\ ${ }^{3}$ Institut für Bienenkunde (Polytechnische Gesellschaft), Fachbereich Biowissenschaften der Goethe-Universität \\ Frankfurt am Main, Karl-von-Frisch-Weg 2, 61440 Oberursel, Germany \\ ${ }^{4}$ Division of Entomology (Paleoentomology), Natural History Museum, and Department of Ecology \\ \& Evolutionary Biology, 1501 Crestline Drive - Suite 140, University of Kansas, Lawrence, \\ Kansas 66049-2811, USA
}

Received 2 June 2008 - Revised and acepted 8 August 2008

\begin{abstract}
The presence of an adventitious distal abscissa in the forewing venation of honey bees is recorded. The vein arises from the posterior quarter of the second submarginal cell, on the apical surface of the $2 r s-m$ crossvein. The homology of this vein is discussed and its presence broadly compared across Hymenoptera so as to establish its correct identity. Based on the overall homology of hymenopteran wing venation it is concluded that this is a reacquisition the vein " $R s_{2}$ " and we accordingly tentatively term it " $a R s_{2}$ ". The $a R s_{2}$ was found in both Apis cerana Fabricius and A. mellifera Linnaeus at moderate frequencies, although it predominantly occurs in northeast Asian populations of the former. Species of the giant honey bees (Megapis) and dwarf honey bees (Micrapis) were found to lack the vein entirely, while the vein was found at low levels in other Asian lineages (Apis s.str.). The predilection to possess the vein appears to be a trait supporting the cavity-nesting honey bee clade (Apis s.str.).
\end{abstract}

comparative morphology / Apini / wing venation / homology / Apis

\section{INTRODUCTION}

The forewing venation of honey bees is quite distinctive and can be easily recognized from the pattern and shape of veins seen in other lineages of corbiculate or other bees (e.g., Ruttner, 1988; Engel, 1998, 1999, 2006; Michener, 2007). This overall pattern of venation has been relatively stable across Apis evolutionary history as it is presently understood, with relatively minor changes in the overall shape of the submarginal cells and position of the $1 \mathrm{cu}-\mathrm{a}$ crossvein relative to the bi-

Corresponding author: M.S. Engel, msengel@ku.edu

* Manuscript editor: Stan Schneider furcation of the combined medial and cubital stem (e.g., Ruttner et al., 1986; Ruttner, 1988; Engel, 1998, 1999, 2006: Fig. 1). Given this relative consistency it was remarkable to discover that with some degree of frequency populations of several species exhibited a unique apical modification of the $2 r s-m$ crossvein, resembling the apical abscissa of a principal longitudinal vein. The appearance of this adventitious vein in several species and with relatively high frequencies indicates that it is not a rare teratology and may represent the reacquisition of a vein long suppressed among most lineages of Hymenoptera.

Herein we provide a brief account of this adventitious vein in the forewing of honey 


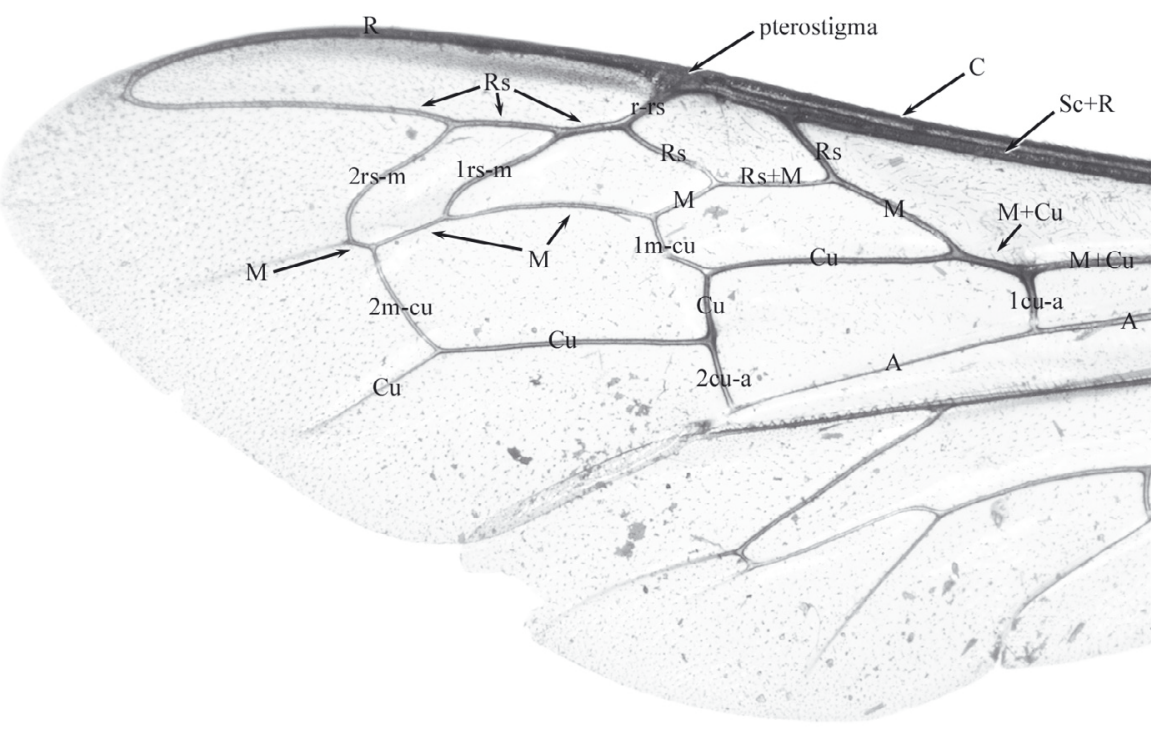

Figure 1. Forewing of typical Apis cerana Fabricius (specimen from Sri Lanka, preserved in the University of Kansas Natural History Museum), with vein identities labeled (photomicrograph by M.S. Engel).

bees in order to bring it to the attention of apidologists. We provide an overview of its distribution and frequency of occurrence in all presently recognized honey bee species (sensu Engel, 1999), as well as prominent subspecific populations widely regarded by other authors as distinct species. Lastly, we attempt to homologize this vein into the broader system of hymenopteran wing venation and briefly comment on its phylogenetic distribution. Herein we employ Apis s.str. for the clade comprising the cavity-nesting honey bees (Engel, 1999) and Apis s.lato for the genus as a whole, encompassing the giant, dwarf, and various extinct honey bee lineages.

\section{MATERIALS AND METHODS}

Forewings of representative Apis populations were compiled from a total of 287 colonies covering the currently known species of the genus Apis. Special attention was given to the Eastern Honey Bee Apis cerana Fabricius and the Western Honey Bee A. mellifera Linnaeus, both covering the most extensive geographical ranges (Tab. I). As the subspecific classification of $A$. cerana is in flux, the species was arbitrarily subdivided according to geographic units while A. mellifera was structured by subspecies according to Ruttner (1988) and Engel (1999). In addition, this species was substructured according to the four morphometric lineages $\mathrm{M}$ ("Mellifera"), C ("Carnica"), O ("Oriental"), and A ("African") of Ruttner (1988). The majority of the A. mellifera forewings were taken from the collection of the Bee Institute in Oberursel, while most $A$. cerana forewings from China were from the collection of the Eastern Bee Research Institute of Yunnan, as documented in Ken et al. (2008). Apis mellifera samples were those regarded as reference samples within the Oberursel collection, as described by Ruttner (1988). Forewings of the other Apis species/subspecies (A. koschevnikovi Enderlein, A. nigrocincta Smith, A. cerana nuluensis Tingek et al., A. florea Fabricius, A. andreniformis Smith, A. dorsata Fabricius, A. dorsata laboriosa Smith) were sampled from South Asia and Southeast Asia, including the countries of Malaysia, Thailand, Nepal, India, Indonesia, and southwestern China. Due to the much lower number of samples available, these were not further substructured. Lastly, forewings from representative outgroup lineages were examined for the presence of the adventitious vein - Meliponini (Melipona, Trigona, Dactylurina, Liotrigona, Proplebeia, Cretotrigona), Melikertini 
Table I. Distribution of occurrence of adventitious distal abscissa of $2 r s-m$ crossvein ("aRs $s_{2}$ ") in Apis cerana Fabricius and A. mellifera Linnaeus. Lengths are provided in units of $1 / 100 \mathrm{~mm}\left(10^{-5} \mathrm{~m}\right)$. "South China" as listed here encompasses Guangdong, Guanggxi, and Hujian.

\begin{tabular}{|c|c|c|c|c|c|c|c|c|c|c|c|}
\hline Location & $\begin{array}{c}\# \\
\text { Colonies } \\
\end{array}$ & $\begin{array}{c}\# \\
\text { Forewings } \\
\end{array}$ & $\begin{array}{c}\text { Forewing } \\
\text { length }\end{array}$ & $\begin{array}{c}\text { Forewing } \\
\text { width }\end{array}$ & $\begin{array}{l}\text { \# with } \\
\text { " } a R s_{2} \text { " }\end{array}$ & $\begin{array}{l}\text { \% with } \\
\text { "aRs } s_{2} \text { " }\end{array}$ & $\begin{array}{c}\text { Maximum } \\
\text { length }\end{array}$ & $\begin{array}{c}\text { Minimum } \\
\text { length }\end{array}$ & Mean & SD & SE \\
\hline \multicolumn{12}{|c|}{ - Apis cerana Fabricius - } \\
\hline Japan & 4 & 80 & 858.48 & 292.05 & 49 & $61.25 \%$ & 17.073 & 2.439 & 6.786 & 2.67 & 0.679 \\
\hline Korea & 4 & 80 & 858.26 & 295.08 & 48 & $60.00 \%$ & 17.073 & 2.439 & 5.726 & 3.73 & 0.769 \\
\hline Jilin & 4 & 45 & 858.30 & 298.84 & 21 & $46.67 \%$ & 12.195 & 2.439 & 5.458 & 3.26 & 0.712 \\
\hline Hubei & 6 & 90 & 869.06 & 301.16 & 8 & $8.89 \%$ & 4.878 & 2.439 & 3.049 & 1.129 & 0.3992 \\
\hline Hunan & 4 & 60 & 860.72 & 300.82 & 3 & $5.00 \%$ & 7.317 & 2.439 & 4.878 & 2.439 & 1.4082 \\
\hline Gangshu & 4 & 60 & 892.96 & 308.80 & 8 & $13.33 \%$ & 4.878 & 2.439 & 3.049 & 1.129 & 0.3992 \\
\hline South China & 5 & 75 & 844.24 & 291.74 & 1 & $1.33 \%$ & - & - & 2.439 & - & - \\
\hline Sichuan & 2 & 30 & 837.44 & 289.82 & 4 & $13.33 \%$ & 4.878 & 2.439 & 3.659 & 2.439 & 1.2195 \\
\hline Yunnan & 26 & 390 & 834.50 & 296.30 & 10 & $2.56 \%$ & 4.878 & 2.439 & 2.927 & 1.028 & 0.3252 \\
\hline Philippines & 10 & 150 & - & - & 1 & $0.67 \%$ & - & - & 1.462 & - & - \\
\hline Thailand & 8 & 120 & 777.90 & 271.38 & 0 & - & - & - & - & - & - \\
\hline Vietnam & 12 & 180 & 804.59 & 278.31 & 7 & $3.89 \%$ & 4.878 & 2.439 & 3.136 & 1.190 & 0.4498 \\
\hline Nepal & 4 & 65 & 843.67 & 293.68 & 1 & $1.54 \%$ & - & - & 1.95 & - & - \\
\hline India & 3 & 45 & 789.23 & 274.47 & 0 & - & - & - & - & - & - \\
\hline Indonesia & 4 & 60 & - & - & 1 & $1.67 \%$ & - & - & 2.439 & - & - \\
\hline \multicolumn{12}{|c|}{ - Apis mellifera Linnaeus - } \\
\hline A. m. mellifera & 6 & 60 & 938.10 & 302.93 & 0 & - & - & - & - & - & - \\
\hline iberiensis & 2 & 20 & 922.60 & 309.80 & 4 & $20.00 \%$ & 18.46 & 6.34 & 10.59 & 5.42 & 2.71 \\
\hline carnica & 7 & 70 & 979.83 & 333.80 & 7 & $10.00 \%$ & 10.88 & 1.00 & 4.56 & 4.03 & 1.52 \\
\hline macedonica & 4 & 40 & 921.25 & 311.89 & 0 & - & - & - & - & - & - \\
\hline cecropia & 5 & 50 & 919.14 & 309.53 & 2 & $4.00 \%$ & 7.84 & 3.28 & 5.56 & 3.23 & 2.28 \\
\hline ligustica & 5 & 50 & 916.32 & 321.60 & 0 & - & - & - & - & - & - \\
\hline caucasica & 7 & 70 & 936.46 & 315.11 & 6 & $8.57 \%$ & 11.20 & 1.00 & 5.14 & 4.75 & 1.94 \\
\hline
\end{tabular}


Table I. Continued.

\begin{tabular}{|c|c|c|c|c|c|c|c|c|c|c|c|}
\hline Location & $\begin{array}{c}\# \\
\text { Colonies }\end{array}$ & $\begin{array}{c}\text { \# } \\
\text { Forewings }\end{array}$ & $\begin{array}{c}\text { Forewing } \\
\text { length }\end{array}$ & $\begin{array}{c}\text { Forewing } \\
\text { width }\end{array}$ & $\begin{array}{l}\text { \# with } \\
\text { " } a R s_{2} \text { " }\end{array}$ & $\begin{array}{l}\% \text { with } \\
\text { " } a R s_{2} \text { " }\end{array}$ & $\begin{array}{l}\text { Maximum } \\
\text { length }\end{array}$ & $\begin{array}{l}\text { Minimum } \\
\text { length }\end{array}$ & Mean & $\mathrm{SD}$ & SE \\
\hline anatoliaca & 6 & 60 & 910.67 & 308.00 & 3 & $5.00 \%$ & 6.55 & 3.08 & 4.75 & 1.74 & 1.00 \\
\hline remipes & 6 & 60 & 905.93 & 305.03 & 19 & $31.67 \%$ & 17.54 & 1.00 & 8.93 & 5.59 & 1.28 \\
\hline meda & 6 & 60 & 868.98 & 298.75 & 1 & $1.67 \%$ & 18.72 & 18.72 & 18.72 & - & - \\
\hline cypria & 5 & 50 & 892.24 & 302.44 & 1 & $2.00 \%$ & 3.44 & 3.44 & 3.44 & - & - \\
\hline adami & 5 & 50 & 920.36 & 305.52 & 2 & $4.00 \%$ & 7.14 & 1.00 & 4.07 & 4.34 & 3.07 \\
\hline syriaca & 6 & 60 & 849.63 & 282.33 & 2 & $3.33 \%$ & 4.62 & 1.00 & 2.81 & 2.56 & 1.81 \\
\hline siciliana & 6 & 60 & 903.11 & 308.93 & 0 & - & - & - & - & - & - \\
\hline ruttneri & 5 & 50 & 873.37 & 292.83 & 3 & $6.00 \%$ & 9.73 & 0.99 & 6.65 & 4.91 & 2.83 \\
\hline intermissa & 6 & 60 & 893.07 & 298.45 & 1 & $1.67 \%$ & 3.08 & 3.08 & 3.08 & - & - \\
\hline sahariensis & 4 & 40 & 928.56 & 310.96 & 0 & - & - & - & - & - & - \\
\hline lamarckii & 5 & 50 & 834.24 & 278.68 & 0 & - & - & - & - & - & - \\
\hline jemenitica & 7 & 70 & 768.20 & 266.01 & 3 & $4.29 \%$ & 8.97 & 4.87 & 7.18 & 2.10 & 1.21 \\
\hline litorea & 6 & 60 & 736.50 & 256.90 & 1 & $1.67 \%$ & 1.00 & 1.00 & 1.00 & - & - \\
\hline scutellata & 6 & 60 & 890.47 & 305.10 & 1 & $1.67 \%$ & 10.09 & 10.09 & 10.09 & - & - \\
\hline monticola & 5 & 50 & 895.67 & 303.64 & 2 & $4.00 \%$ & 7.69 & 1.00 & 4.35 & 4.73 & 3.35 \\
\hline adansonii & 7 & 70 & 798.12 & 271.64 & 2 & $2.86 \%$ & 1.00 & 1.00 & 1.00 & - & - \\
\hline unicolor & 3 & 30 & 872.47 & 294.73 & 0 & - & - & - & - & - & - \\
\hline capensis & 4 & 40 & 939.50 & 315.45 & 2 & $5.00 \%$ & 1.00 & 1.00 & 1.00 & - & - \\
\hline M branch & 23 & 230 & 909.27 & 301.56 & 8 & $3.48 \%$ & 18.46 & 0.99 & 8.18 & 5.25 & 1.86 \\
\hline $\mathrm{C}$ branch & 27 & 270 & 931.11 & 318.27 & 9 & $3.33 \%$ & 10.88 & 1.00 & 4.79 & 3.70 & 1.23 \\
\hline O branch & 41 & 410 & 898.28 & 302.69 & 34 & $8.29 \%$ & 18.72 & 1.00 & 7.37 & 5.53 & 0.95 \\
\hline A branch & 43 & 430 & 831.41 & 283.56 & 10 & $2.33 \%$ & 10.09 & 1.00 & 4.82 & 3.65 & 1.15 \\
\hline
\end{tabular}


Table II. Distribution of occurrence of adventitious distal abscissa of $2 r s-m$ crossvein (" $a R s_{2}$ ") in other honey bee taxa. Lengths are provided in units of $1 / 100 \mathrm{~mm}\left(10^{-5} \mathrm{~m}\right)$.

\begin{tabular}{|c|c|c|c|c|c|c|c|c|}
\hline Taxon & $\begin{array}{c}\# \\
\text { Colonies }\end{array}$ & $\begin{array}{c}\# \\
\text { Forewings }\end{array}$ & $\begin{array}{l}\text { \# with } \\
\text { " } a R s_{2} \text { " }\end{array}$ & $\begin{array}{l}\text { \% with } \\
\text { " } a R s_{2} \text { " }\end{array}$ & $\begin{array}{l}\text { Maximum } \\
\text { length }\end{array}$ & $\begin{array}{c}\text { Minimum } \\
\text { length }\end{array}$ & Mean & SD \\
\hline \multicolumn{9}{|c|}{-Apis s.str. - } \\
\hline A. koschevnikovi Enderlein & 10 & 100 & 8 & $8.00 \%$ & 11.70 & 1.00 & 3.09 & 3.96 \\
\hline A. nigrocincta Smith & 4 & 40 & 2 & $5.00 \%$ & 6.98 & 1.00 & 2.99 & 4.46 \\
\hline A. c. nuluensis Tingek et al. & 9 & 90 & 2 & $2.22 \%$ & 4.42 & 1.00 & 2.71 & 2.42 \\
\hline \multicolumn{9}{|c|}{-Micrapis - } \\
\hline A. florea Fabricius & 7 & 70 & 0 & - & - & - & - & - \\
\hline A. andreniformis Smith & 6 & 60 & 0 & - & - & - & - & - \\
\hline \multicolumn{9}{|c|}{ - Megapis - } \\
\hline A. dorsata Fabricius & 6 & 60 & 0 & - & - & - & - & - \\
\hline A.d. laboriosa Smith & 6 & 60 & 0 & - & - & - & - & - \\
\hline
\end{tabular}

(Melikertes, Succinapis), Electrapini (Electrapis, Protobombus, Thaumastobombus), Electrobombini (Electrobombus), Bombini (Bombus), Euglossini (Euglossa, Exaerete, Eufriesea, Eulaema, Aglae).

Measurements were performed using a stereomicroscope and a computer-aided measuring system based on a video system and measuring program (Bee2 ${ }^{\odot}$, Meixner, 2004). In the case of A. mellifera forewings were first photographed and then analysed by Sigmascan ${ }^{\circledR}$ pro (2002) imaging software. At least ten forewings were sampled from each colony and examined for the presence of the adventitious distal abscissa. This was scored as present only if a measurable vein length could be detected, while slight thickenings at the tentative junction were ignored. If present, then the length of the vein was measured. Tables I and II give the numbers colonies and forewings per subdivision, and the dimensions of the wings in terms of wing length and width. In addition, the tables provide the number and percentage of forewings where the adventitious vein could be detected. Further, for those samples where the adventitious vein was present, maximum and minimum lengths as well as median, standard deviation, and standard error of the adventitious vein are provided.

\section{RESULTS}

The adventitious distal abscissa was found in almost all populations of $A$. cerana that were studied (Tab. I) with an overall proportion of $10.6 \%$. The adventitious vein was present in very high proportions of about $40-60 \%$ in the northern populations of Japan,
Korea, and northeastern China (Jilin), although it was less frequent in the other locations of China (1-13\%) and Vietnam. While it was absent in the southern, mainland A. cerana populations of Thailand and India, the vein did occur at low proportions of $1-2 \%$ in the Sundaland island populations of Indonesia and the Philippines. Likewise, the length of the vein decreased with the frequency of its occurrence from 0.068 in the northern populations to about $0.02 \mathrm{~mm}$ in the southern populations.

In $A$. mellifera the adventitious vein occurred at an overall proportion of $4.5 \%$, which is only half as frequent as in A. cerana. In about $40 \%$ of the subspecies frequencies did not exceed $2 \%$. Frequencies of more than $10 \%$ were recorded in A. m. carnica Pollmann and A. m. iberiensis Engel, and it was particularly frequent in $A$. $m$. remipes Gerstäcker where it reached $32 \%$. Concerning the morphometric lineages defined by Ruttner (1988), the adventitious vein was least frequent in the "African" lineage $(2.3 \%)$, occurred in slightly higher frequencies in the "Mellifera" and "Carnica" lineages (3.5 and $3.3 \%$, respectively), but was distinctly more frequent in the "Oriental" lineage $(8.3 \%)$. The length of the adventitious vein in the subspecies ranged between 0.01 and $0.18 \mathrm{~mm}$, with an overall mean of $0.07 \mathrm{~mm}$, only marginally exceeding that of A. cerana. Again, it was longest in those subspecies where it was found with higher frequency. No correlation was found with wing size in A. mellifera. 
The adventitious distal abscissa was also found in the other cavity-nesting Apis populations, namely A. koschevnikovi, A. nigrocincta, and $A$. c. nuluensis although at inconspicuous frequencies ranging between $2-8 \%$ and with an overall length around $0.03 \mathrm{~mm}$ (Tab. II). However, it was absent in the 250 wings from 25 colonies of open-nesting dwarf honey bees (subgenus Micrapis) and giant honey bees (subgenus Megapis) (Tab. II).

\section{DISCUSSION}

The story of hymenopteran wing venation is one of fusion and confusion. The overall homology of wing veins in the order has been addressed by various authors (e.g., Robertson, 1900; Ross, 1936; Eady, 1974; Mason, 1990; Huber and Sharkey, 1993). A complete overview of the various homologies and variants across the order is well beyond the scope of the present contribution. Nonetheless, honey bees and bees in general (Apoidea: Anthophila, sensu Engel, 2005) are highly derived wasps and, as such, their wing venation must be interpreted in the context of hymenopteran, particularly aculeate, phylogeny and morphological evolution. The wing venation of bees was recently revised slightly and standardized with terminology employed elsewhere in the Hymenoptera, and contextualized within a modern understanding of insect wing vein homologies (Engel, 2001a). These vein identities are summarized in Figure 1 for Apis cerana Fabricius. The adventitious vein observed in various populations of several species arises from the posterior quarter of the outer surface of the $2 r s-m$ crossvein (the second transverse-cubital or second submarginal crossvein of some antiquated nomenclatural systems: e.g., Michener, 1944, 2007). The vein extends outward toward the apical margin of the forewing, slightly tapering at its apex in the same fashion as the main longitudinal veins at their apices, e.g., the medial $(M)$ and cubital $(\mathrm{Cu})$ vein apices (cf. Figs. 1, 2).

While in most Hymenoptera vein Rs comprises a single vein, the basalmost family of the order, i.e., sawflies of the family Xyelidae, as well as various living and extinct outgroups to Hymenoptera have a multiply-branched $R s-R s_{1}$ and $R s_{2}$ (e.g., Grimaldi and Engel, 2005). If the $R s_{1}$ of Xyelidae was lost in Neohymenoptera (all lineages of Hymenoptera excluding Xyelidae: sensu Grimaldi and Engel, 2005 ), then the " $R s$ " in most hymenopterans would be accordingly $R s_{2}$. Under such a scenario the adventitious vein observed in Apis would perhaps represent the reacquisition of an anterior branch of the medial vein $\left(M_{1}\right)$ given that it is positioned between the posterior-most branch of $R s$ and $M$. However, given that the medial vein is not branched in basal lineages of Hymenoptera the possibility that the adventitious vein represents an anterior branch of $M$ (as in other mecopteroids) is exceedingly unlikely. As such the identity of this adventitious vein as a reacquisition of $R s_{2}$ or as an enigmatic teratology resembling a main longitudinal vein are the most conservative and well justified interpretations. This would indicate that the " $R s$ " of most Hymenoptera is $R s_{1}$ and that $R s_{2}$ was lost in the ancestor of all Hymenoptera beyond Xyelidae, i.e., the initial loss of $R s_{2}$ would represent a potential synapomorphy of the clade Neohymenoptera (sensu Grimaldi and Engel, 2005). Of these two scenarios, the de novo creation of such a convergent stub is less well supported and clearly ad hoc. Alternatively, the reacquisition of $R s_{2}$ is known from elsewhere in the Hymenoptera (e.g., Pelecinidae: Johnson, 1998; Engel, 2002; Engel and Grimaldi, 2006) and accordingly provides the strongest evidence for the possibility that the adventitious vein in Apis is a primary homologue (i.e., shares similar topological identities: sensu Remane, 1952). Given the available evidence we therefore interpret this vein as a reacquisition of $R s_{2}$, terming it " $a R s_{2}$ " in accordance with its adventitious nature.

The functional implication of $a R s_{2}$, if any exists, is not understood, nor is the reason for its more predominant occurrence in particular northeastern populations of A. cerana as compared to other geographic regions or species. Regardless, the predilection for the acquisitioning of this adventitious vein is confined to the cavity-nesting honey bees and this predilection could be interpreted as a synapomorphy for this clade. Recent phylogenetic 


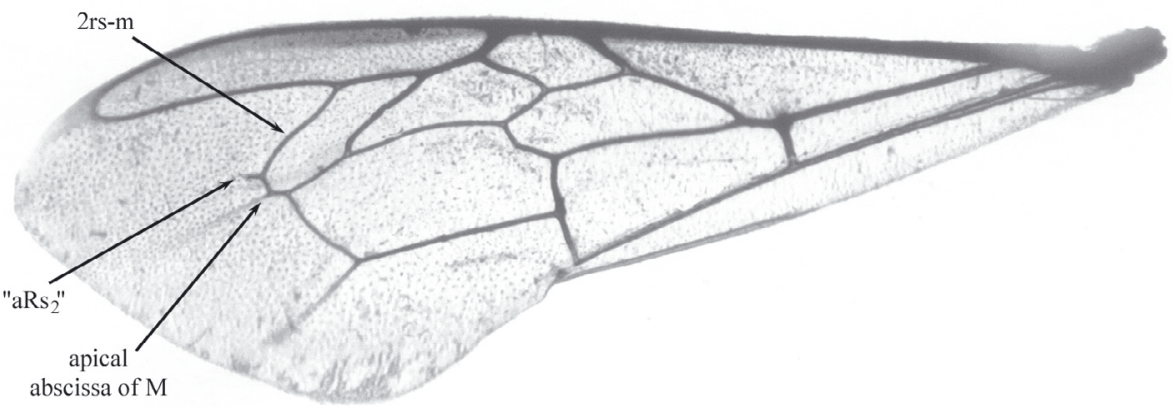

Figure 2. Forewing of Apis cerana Fabricius depicting the adventitious distal abscissa, " $a R s_{2}$ " (photomicrograph by Tan Ken).

studies based on molecular, ethological, morphological, and paleontological evidence support the hypothesis that Apini is most closely related to a clade comprising Meliponini (stingless bees) and the extinct tribe Melikertini (e.g., Schultz et al., 1999, 2001; Engel, 2001a, 2001b; Serrão, 2001; Noll, 2002; Cardinal and Packer, 2007; Hinojosa-Díaz and Engel, 2008). Sister to these three is the extinct tribe Electrapini, with the extinct Electrobombini as the next most basal relative, followed by Bombini (bumble bees), and then Euglossini (orchid bees). An examination of representatives of these tribes as well as three extinct species of Apis - A. (Megapis) lithohermaea Engel, A. (Synapis) henshawi Cockerell, and A. (Cascapis) armbrusteri Zeuner (Engel, pers. obs.) - did not reveal the presence of $a R s_{2}$ in any of the lineages further suggesting that its absence in Micrapis and Megapis is plesiomorphic for the Apini and derived among the cavity-nesting honey bees. Such an interpretation further supports the phylogenetic hypothesis of most authors that Apis s.str. (= subgenus Apis; i.e., excluding Megapis, Micrapis, Synapis, Cascapis, and Priorapis) is monophyletic (e.g., Engel \& Schultz, 1997; Engel, 1999, 2006; Raffiudin and Crozier, 2007).

It is interesting to note that the occurrence of $a R s_{2}$ is somewhat structured along a NorthSouth gradient in A. cerana populations, with significantly higher frequencies in northeast- ern Asia than any other region. The frequency drops precipitously in southern China and then again further South in Asia or in the Southeast Asian islands, almost to negligible levels. What might account for such a demarcating distribution of $a R s_{2}$ in Asia is not entirely clear as there appears to be no functional correlation of this vein with the overall flight dynamics of the bees along this latitudinal gradient. Moreover, while the pattern is weaker, the higher frequency of $a R s_{2}$ in A. mellifera populations was found in the "Oriental" lineage (sensu Ruttner, 1988) and thereby roughly approximating an East-West gradient, orthogonal to the gradient in A. cerana. In addition, there is no correlation between presence or length of $a R s_{2}$ with forewing size in A. mellifera, and there is only a slight (again, perhaps negligible) correlation with forewing size in A. cerana. What selective pressures, if any, might be acting to maintain the presence and pattern of occurrence of $a R s_{2}$ is entirely open to speculation at this time.

\section{ACKNOWLEDGEMENTS}

We thank M. Beck for help with the analysis of the A. mellifera forewings, and two anonymous reviewers for their constructive comments on the manuscript. Financial support was granted to TK by the Xishuangbanna Tropical Botanical Garden, Chinese Academy of Science, National Natural Scientific Research Program of China-2006 
(30671592). Additionally, partial support was provided by National Science Foundation (USA) grant EF-0341724 (to MSE). This is a contribution of the Division of Entomology, University of Kansas Natural History Museum.

\section{Une abscisse distale supplémentaire dans l'aile antérieure des abeilles du genre Apis (Hymenop- tera, Apidae).}

Apis / Apini / morphologie comparative / homologie / vénation alaire

\begin{abstract}
Zusammenfassung - Eine zusätzliche distale Abszisse im Vorderflügel der Honigbienen (Hymenoptera: Apidae: Apis). Es wird eine zusätzliche Ader im Vorderflügel der Honigbiene beschrieben. Falls vorhanden, erscheint diese Ader am hinteren zur Spitze hin gelegenen Rand der außengelegenen submarginalen Zelle. Um die korrekte Identität dieser Ader zu ermitteln, wurde eine vergleichende Untersuchung unter Einbeziehung weiterer Linien von Bienen und Wespen angestellt (Ordnung Hymenoptera). Auf Grundlage dieses breit angelegten Vergleichs wurde darauf geschlossen, dass es sich bei der zusätzlichen Ader um ein Wiedererscheinen des hintestgelegenen Zweiges des Radialsektors handelt. Diese Ader ist bei den meisten Hymenopteren verloren gegangen aber bei einigen abgeleiteten Linien, wie z.B. der Wespenfamilie Pelecinidae, erneut aufgetreten. Dementsprechend wurde diese Ader bei den Honigbienen vorläufige als " $a R s_{2}$ " bezeichnet und damit angezeigt, dass es sich um ein sekundäres Wiederauftreten handelt. Das Auftreten dieser Ader wurde in Populationen aller Honigbienenarten und fast sämtlicher Unterarten über ihr Verbreitungsgebiet hinweg untersucht. Die " $a R s_{2}$ " Ader wurde sowohl bei Apis cerana Fabricius als auch bei A. mellifera Linnaeus in mäßiger Häufigkeit gefunden, wobei sie bei der erstgenannten Art überwiegend in den Populationen von Japan, Korea und der Jilin Provinz (Volksrepublik China) auftrat. Bei A. cerana wurde eine schwach ausgeprägte kontinuierliche Abnahme der Häufigkeit von Norden nach Süden vorgefunden, bei A. mellifera dagegen von Osten nach Westen. Bei anderen asiatischen höhlenbrütenden Honigbienen (Untergattung Apis s.str.) kam diese Ader nur in zu vernachlässigender Häufigkeit vor, bei den Zwerghonigbienen (Untergattung Micrapis) und den Riesenhonigbienen (Untergattung Megapis) fehlte sie ganz. Die evolutionären Folgerungen dieser Ader werden kurz angesprochen, ihre Funktion, falls es eine gibt, bleibt ungewiss.
\end{abstract}

\section{Vergleichende Morphologie / Apini / Flügelade-} rung / Homologie / Apis

\section{REFERENCES}

Cardinal S., Packer L. (2007) Phylogenetic analysis of the corbiculate Apinae based on morphology of the sting apparatus (Hymenoptera: Apidae), Cladistics 23, 99-118.

Eady R.D. (1974) The present state of nomenclature of wing venation in the Braconidae (Hymenoptera): Its origins and comparison with related groups, J. Entomol. B Taxon. 43, 63-72.

Engel M.S. (1998) Fossil honey bees and evolution in the genus Apis (Hymenoptera: Apidae), Apidologie 29, 265-281.

Engel M.S. (1999) The taxonomy of Recent and fossil honey bees (Hymenoptera: Apidae; Apis), J. Hymenoptera Res. 8, 165-196.

Engel M.S. (2001a) A monograph of the Baltic amber bees and evolution of the Apoidea (Hymenoptera), Bull. Am. Mus. Nat. Hist. 259, 1-192.

Engel M.S. (2001b) Monophyly and extensive extinction of advanced eusocial bees: Insights from an unexpected Eocene diversity, Proc. Natl. Acad. Sci. USA 98, 1661-1664.

Engel M.S. (2002) The fossil pelecinid Pelecinopteron tubuliforme Brues in Baltic amber (Hymenoptera: Pelecinidae), J. Hymenoptera Res. 11, 5-11.

Engel M.S. (2005) Family-group names for bees (Hymenoptera: Apoidea), Am. Mus. Novitates 3476, 1-33.

Engel M.S. (2006) A giant honey bee from the middle Miocene of Japan (Hymenoptera: Apidae), Am. Mus. Novitates 3504, 1-12.

Engel M.S., Grimaldi D.A. (2006) A diminutive pelecinid wasp in Cretaceous amber from New Jersey (Hymenoptera: Pelecinidae), Northeast. Nat. 13, 291-297.

Engel M.S., Schultz T.R. (1997) Phylogeny and behavior in honey bees (Hymenoptera: Apidae), Ann. Entomol. Soc. Am. 90, 43-53.

Grimaldi D., Engel M.S. (2005) Evolution of the insects, Cambridge Univ. Press, Cambridge.

Hinojosa-Díaz I.A., Engel M.S. (2008) Juxtocellar structures in euglossine bees: A new character for corbiculate studies (Hymenoptera: Apidae), Beitr. Entomol. 58, 97-105.

Huber J.T., Sharkey M.J. (1993) Structure, in: Goulet H., Huber J.T. (Eds.), Hymenoptera of the world: An identification guide to families, Agriculture Canada, Ottawa, pp. 13-59.

Johnson N.F. (1998) The fossil pelecinids Pelecinopteron Brues and Iscopinus Kozlov (Hymenoptera: Proctotrupoidea: Pelecinidae), Proc. Entomol. Soc. Wash. 100, 1-6.

Ken T., Hepburn H.R., Radloff S.E., Fuchs S., Xian F., Lianjiang Z., Mingxian Y. (2008) Multivariate morphometric analysis of the Apis cerana of China, Apidologie 39, 343-353.

Mason W.R.M. (1990) Cubitus posterior in Hymenoptera, Proc. Entomol. Soc. Wash. 92, 93-97. 
Meixner A. (2004) Bee2: Morphometric Software (1996-2004) Frankfurt, Germany.

Michener C.D. (1944) Comparative external morphology, phylogeny, and a classification of the bees (Hymenoptera), Bull. Am. Mus. Nat. Hist. 82, $151-326$.

Michener C.D. (2007) The bees of the world, 2nd ed., Johns Hopkins Univ. Press, Baltimore.

Noll F. (2002) Behavioral phylogeny of corbiculate Apidae (Hymenoptera; Apinae), with special reference to social behavior, Cladistics 18, 137-153.

Peixoto E.B.M.I., Serrão J.E. (2001) A comparative study of the cardia and cardiac valves in corbiculate bees (Hymenoptera, Apinae), Sociobiology $37,707-721$.

Raffiudin R., Crozier R.H. (2007) Phylogenetic analysis of honey bee behavioral evolution, Mol. Phylogenet. Evol. 43, 543-552.

Remane A. (1952) Die Grundlagen des natürlichen Systems der vergleichenden Anatomie und der Phylogenetik, Geest und Portig, Leipzig.

Robertson C. (1900) Homologies of the wing veins of Hymenoptera, Science 11, 112-113.
Ross H.H. (1936) The ancestry and wing venation of the Hymenoptera, Ann. Entomol. Soc. Am. 29, 99-109.

Ruttner F. (1988) Biogeography and taxonomy of honeybees, Springer Verlag, Berlin.

Ruttner F., Wilson E.C., Snelling R., Vorwohl G., Kauhausen D. (1986) Die Evolution des Flügelgeäders der Honigbienen, Apidologie 17, 348-350.

Schultz T.R., Engel M.S., Prentice M. (1999) Resolving conflict between morphological and molecular evidence for the origin of eusociality in the corbiculate bees (Hymenoptera: Apidae): A hypothesis-testing approach, Univ. Kans. Nat. Hist. Mus. Spec. Publ. 24, 125-138.

Schultz T.R., Engel M.S., Ascher J.S. (2001) Evidence for the origin of eusociality in the corbiculate bees (Hymenoptera: Apidae), J. Kans. Entomol. Soc. $74,10-16$.

Serrão J.E. (2001) A comparative study of the proventricular structure in corbiculate Apinae (Hymenoptera, Apidae), Micron 32, 379-385.

Sigmascan ${ }^{\circledR}$ Pro (2002) Imaging Software (2002) Systat Software Inc. 